\title{
BUILDING LEARNING COMMUNITIES IN TERMS OF IMPROVING ENGLISH VOCABULARY THROUGH KOREAN DRAMA WITH ENGLISH SUBTITLE
}

\author{
Lida Holida Mahmud, Tryana \\ Universitas Pamulang \\ dosen00420@unpam.ac.id
}

\begin{abstract}
The research explored the issues of the English teaching method as a foreign language. The purpose of the study is to improve students' vocabulary of English. It focused on teaching technique in English vocabulary by using Korean Drama with English sub-title. In particular, it focused on students' feelings and behavior in line with a student's test result of whether or not the implementation of Korean Drama with English subtitles in English teaching is beneficial for students' improvement of English vocabulary. The literature review highlighted the connection between teaching methods and building learning community. Since the meaning of building learning communities is broad, the research focused on the motivation in watching Korean drama, it was linked to build learning community in terms of improving English vocabulary. The method employed during the research phase of this project has been done to generate data through questionnaires, interviews, and tests. Since the aim of the research is to see the possibility of Korean Drama in improving students' vocabulary in English, it was important to produce qualitative elicited partly through the use of test results and open questions in questionnaires and interviews. This study employed 70 respondents from the first semester students of the English Department in Universitas Pamulang as samples of the population. From the data analyses, it was found that there are some aspects that should be improved in the project itself such as feedback, support in continuing professional development of lectures and monitoring and also evaluation. From the findings, the research suggests that developing teaching should be in line with a system for fostering teachers to follow up and assist their abilities to sustain professional development independently, might assist in improving student's competency.
\end{abstract}

\section{Key Words: English subtitle, Korean Drama, learning communities, motivation and Vocabulary.}

\section{INTRODUCTION}

The latest issue in Indonesia is that most English teachers/lecturers face challenges of how to serve students with teaching and learning models offering an attractive approach. Most Indonesian students still believe the paradigm that it is a boring subject. This leads the issue that vocabulary appears to be in need of support for subject learning, an environment for teaching that is interesting, creative, innovative, and enjoyable so that it attracts students' interest in subject areas. On this basis, learning communities in terms of teaching method supporting this kind of approach are needed. Many groups claim that they are learning communities. However, they cannot give a precise explanation of what it is. 
Watkins (2005) views a community as a collective of people from different backgrounds who have the cohesion of a vision and a sense of belonging to the group. Then, when the vision is related to learning, the vision of the group is to support teachers' roles in organizing a classroom, covering the social nature of learning, and managing the classroom. Similarly, others view learning communities as having different approaches that bring together individuals who have a curiosity for learning about a given subject (Gabelnick, et al., 1990; Shapiro \& Levine, 1999). This research argues that teaching methodology has the capacity to convince participants for learning communities. Therefore, the main purpose of this research is to explore the possibility of adopting Korean Drama with English subtitle as teaching aid might be desirable in building learning communities in English Vocabulary Class context. This research also reviewed the students' experiences in Universitas Pamulang, which has introduced a Korean Movie with English Subtitle as a teaching aid. This research will begin by addressing educational challenges in English Class in Indonesia.

As a person who works as an English lecturer, the writer is aware of the English teaching-learning process in Indonesia. The government of Indonesia has tried to find ways to improve its people. However, it is noticed that some obstacles have hindered their efforts to ensure students' improvements in English. There are three challenges in English process learning:

First, low teacher competency influences students' ability to learn. In the past, all people who graduated with a degree from an education department were allowed to be teachers without taking a test to prove they had mastered teaching competencies. The government faces a dilemma in discovering a way to persuade these teachers to retire. This phenomenon has led to low-quality classroom activities. It is common for these teachers to persist in using oldfashioned approaches that are teacher centered (MONE, 2005 in Triana, 2006).

Second, the Ministry of Education and Culture (2011) Reported National Exam Result indicated that Indonesian students have a consistently low level of achievement in English. Other data from the English First Report (2018) found that Indonesia has been left behind compared with other Asian countries in speaking English. The data provide evidence that the Indonesian classroom in Indonesia needs improvement in teaching and learning approaches, especially for English.

Third, the World Bank and International Study Association in Mustangin (2018) reports that Indonesia is the lowest grade of reading in East Asia in 2012 with a score of 51.7 under Philippines, Singapore, and Hongkong. This situation has led the Indonesian government to launch Curriculum 2013, a learning approach based on interest, creativity, effectiveness, and enjoyment called Pendekatan Aktif, Kreatif. Effective dan Menyenengkan or PAKEM. The goal of the program is to produce a teaching and learning model that attracts students' interest in learning. In this program, students appear to be a target for competency development.

In this study, therefore, the goal is to explore whether Korean Movies with English Subtitle might contribute to build a learning community or not. However, in order to analyze whether Korean Drama might desirable or not to building learning communities, the theoretical framework of this research explores what Korean Drama is and in what ways Korean Drama is desirable to build learning communities in English class that affect to student's achievement, especially vocabulary.

\section{REVIEW OF LITERATURE}

Vocabulary is critical aspect for language learner. Sutanto (2017 p. 182) shares that vocabulary enables language to use and conversely. It means that vocabulary is directly used in whole elements of conversation; listening, reading, writing and speaking. Without vocabulary, people cannot read, speak and cannot understand what other people say either spoken or written. Jordan in Anggraini (2012) states that teaching vocabulary is the most 
important part of teaching English because the mastery of vocabulary determines four language skills of learners namely: listening, speaking, reading and writing Furthermore, Wallace (in Bakhti \& Marwonto, 2018) argues that there are six principles that must exist in teaching vocabulary:

1. Aims

The objective of teaching vocabulary is to make teacher easier to convey material to students

2. Quantity

Teacher has to select specific theme of material then decided some specific vocabulary items to be learned in terms of the theme. Teachers should start from new words that make students easy to understand.

3. Need

Teachers have to know what diction that students need for their communication. In other words, teacher should update the trend of communication among students that develop continuously.

4. Frequent Exposure and Repetition

In the practice of repetition, the teacher must provide the opportunity for students to use targeted words as often as possible in assignment, reading material and speaking. In other words, teachers lead the entire students' assignment and activities in learning process, like how students speak up to convey his message to the others, to be not separated from targeted words

5. Meaningful Presentation

Teacher must offer targeted words in various ways of application, so the meaning of the targeted word is clear, understandable and not be haziness.

6. Situation and presentation

Teacher leads students to use targeted words in many different contexts. Its purpose is to make students understand the words not only based on dictionary meaning but also on context.

In addition, Allen and Marquez (2011) offers some techniques and strategies in teaching vocabulary as follows:

1. Demonstration

In this technique, teacher demonstrates real object, events, rules and sequence to carry out activity, both directly and through the use of relevant teaching media and material presented, such as teacher may demonstrate the material using real object in the classroom

2. Visual Aid

Visual aids are devices presenting unit of knowledge through auditory visual stimuli to concretize the information to be obtainable and help in making learning practice applicable, real, active and vital (Shabiyala, Hasan, Hamed \& Iqbal, 2015). It leads students learning process experience more real.

3. Verbal explanation

Simple definitions and explanation are carried out in this learning process. Teacher explains and defines targeted words in student's language context or using vocabulary that students have already known the meanings.

From the information above, it is concluded that there should be initial strategy and technique in vocabulary learning process that help students to attain achievement in terms of targeted words. 


\section{Korean Drama with English Subtitle}

Drama is a portrait of real life in a society. It was mentioned by Waluyo (2006) that Drama is an imitation of life that is projected on stage. As well as Waluyo, Esser (2017, p. 411) explores that "drama is a directed role of real-life." One drama that is currently booming in Indonesia today is Korean Drama.

Erwin (2019) reports that Korean drama is a part of the Integrated Korean Industrial Revolution. This industry introduces their culture presented through music, culinary, film and drama. "Endless Love" is first initially as Korean drama entering Indonesia in the 2000s. He also adds that the drama was able to attract many Indonesian people because the story has succeeded in influencing the audience's emotion, through a tear- chilling romantic scene. After the success of "Endless Love", other Korean Dramas began to appear. The success of Korean drama in Indonesia is inseparable from factors of Drama Korean's characteristics favored by Indonesian audiences.

There are 3 factors in Korean Drama which are the reasons why Korean drama is more favorite in Indonesia compared to other types of drama. The first, the storyline presented in Korean drama is not complicated, simple and light. Korean drama serves 10 to 30 episodes. The audience can enjoy it in a short period of time. The audience's curiosity about the storyline can be answered in short days. In contrast, Indonesia's or India's drama (soap opera) usually have hundreds of episodes (200 to 600 episodes). Furthermore, the story of Indonesia's or India's drama does not focus on one problem, it branches off into several problems. Thus, both characters cause Indonesia's and India's drama are boring, Korean drama is preferred over Indonesia's and India's. Second, Korean drama is never separated from the romantic genre. Ani (2017) states that the romantic in the Korean drama scene is not portrayed in an erotic language like western drama. It is exposed through body language, gestures, dialogue which are in line with norms of decency without losing the emotion. Since this reason is considered more appropriate with Indonesian culture and character in terms of norms of decency and morality, Korean Drama becomes popular in Indonesia. The third, Korean drama depicts their beauty and culture like food, culinary and social life. It drives curiosity among Indonesian audiences.

Those phenomena boost Korean entertainment industry to produce hundreds of dramas every year. Some of them are broadcasted in Indonesia through private and cable tv stations using Indonesian dubbing. In addition, the data above also show that all Korean dramas in Indonesia are welcomed by the public. Unfortunately, there are so many Korean dramas that cannot be broadcasted in Indonesia due to the issue of cooperation rules on broadcasting rights. Many of them can be watched on YouTube channel or other Korean drama provider websites. This challenge encourages audiences to use the internet to meet their needs toward Korean drama. The benefit of internet access makes individual to get updated and downloaded Korean Drama. Unfortunately, they are not facilitated with Indonesian subtitles or dubbing. Therefore, most of them are provided in English subtitle, it does not break audiences' will to keep watching. Since English subtitle does not destruct the audience's desires to keep watching Korean drama, in this phase, curiosity in the way of story favored likely appears as motivation to keep watching to drive incidental acquisition towards the English language, in terms of vocabulary.

\section{METHODS}

The research design in this study is classroom action research by using descriptive qualitative method. Since Mettetal (2012) finds that "classroom research action is a method of finding out what works the best in your own classroom, so that you can improve your students learning." It is believed that this research design drives teacher/lecturers involving into self-evaluation for their own problem and seeking the problem solving as well. 
Furthermore, Cresswell (2003) finds that the qualitative method provides depth perspective and detail. It explores in-depth on recording feelings, behaviors, and attitudes. Moreover, qualitative methods provide directness of openness in terms of boosting people to developon their response (p. 15). In this regard, it gives chance to open up new topic areas that is not initially considered before. 1

In line with this, adopting a perspective that is in line with feelings and naturally expressed opinions is the reason for using qualitative methods for this research. It is supported by Marshal and Rossman (2011, p.29) that qualitative study is used to collect information, containing a high proportion of opinion, attitude and personal experiences. This study allows participants to raise issues of concerns in natural setting as Miles, Huberman and Saldjana (2014, p. 10) suggest that "what is important about well- collective data? One major feature is that they focus on naturally occurring, ordinary events in natural settings so that we have a strong handle on what 'real-life' is like."

For data and source, it is decided to use five instruments; document analysis, test, observation, questionnaires and interview, as Denscombe (2014) suggests that different methods are better suited to different circumstances.

The first instrument is document analysis consisting of a review of relevant literature, including research, the exploration of Korean movies with English subtitle. The second instrument is the test results of pre and post-test for "Transitive and Intransitive Verb". The following instrument is observation, Wagner, Kawulich and Gardner (2012) argues that observation help you to identify and guide relationships with informants, to learn how people in the setting interact in social setting in the study. The fourth instrument was questionnaire. The fifth instrument was the interviews. Semi-structured interviews with students. Indeed, it was a challenging experience for me that needed a lot of preparation and practice. As Cohen and Manion (1994, p. 82) state that 'like fishing, interviewing is an activity requiring careful preparation, much patience, and considerable practice if the eventual reward is to be a worthwhile catch'. This investigation aims at gathering perceptions or opinions that involve feeling, beliefs and values, such expressions call for judgments about things rather than simply reporting something. Questionnaires provided written information in response to the question asked by the researcher (Denscombe, 2014) The questionnaire in this investigation will be open questions. Through open questions, respondents are expected to perceive and give opinion more openly and freely than closed question.

The population in this study was New Students (Semester 1) of English Department, Universitas Pamulang. Then 50 students of Universitas Pamulang in English Department were for being sampling area in the study. They are chosen as the sampling with the following reason:

1. Universitas Pamulang consists of multi-ethnic students in Indonesia

2. Most students of English department in Universitas Pamulang of the first semester (new students) are typical of Indonesian' students: fear of speaking English with lecturer, lack of reading book; focus on module material only.

3. Since this project is classroom action research, I believe that my present teaching work in vocabulary class can be handled strongly to reflect the insight as a real-life is like.

It is realized that the sample of students are not likely to be representatives of English students in Indonesia. As such, this study assumes a certain degree of generalization. This could be deemed as both a strength and weakness at the same time. On this basis, one cannot assume that the general themes and issues are applicable to every circumstance and English students in Indonesia. However, the same typical English students in Indonesia are lack of reading and synthesized data from various literature and findings made the study reasonable to attribute generality to recurring themes and issues, particularly improving vocabulary of 
English students in Indonesia.

This study was triangulated the data from questionnaire, test result, document analysis and interview as Cohen \& Manion (1994, p43) suggest "triangular techniques explain more fully, the richness and complexity of human behaviors by studying it from more than one standpoint and it so doing." It probably finds short and unclear responses in questionnaires' result. However, after comparing to the result of interview and test, it is believed that a description how the respondents perceive and behave towards Korean Movies with English Subtitle in improving English vocabulary will be found.

\section{FINDINGS}

From the observation and interview, it was found that the main problem of the students in learning English is lack of motivation. Before starting the class, the researcher explained the material, some students' face showed 'no interest'. Moreover, some of them did not bring dictionary either hard copy or digital. It put them in difficulties when translating English and led them complaining the meaning word to their friends many times. In addition, lack of preparation was also serious barrier in the class. Most students have not read yet the module/material that are going to study. It is marked when they were asked to recall questions due to Vocabulary in terms of Transitive and Intransitive Verb. Some of students were not ready to convey their mind messages into opinions. Furthermore, the pretest score data showed that most students were below passing grade. It proves that all of the obstacles above influence students' mastery of English. In addition, it indicates that new teaching strategy in relying students' motivation and achievement is essentially needed.

The study employed four steps in this project. First step was conducted through observation the class and interview students to find out the problem among students in terms of vocabulary mastery. The second step involved Pre-test to get data of students' score after learning process. This step was allocated time for 45 minutes for learning process and 30 minutes for Pre-Test without notification that the following week the material would be the same. The following week, students were given Treatment (Learning process use Korean Drama with English Subtitle with the same material), then it was continued to post-test to see whether the progress is appearing or not. The result of the pre and post-test was reconfirmed through the questionnaire to ask students' feeling and behavior towards the treatment. Here is the following data result:

Table 1. Students' Score of Pre and Post test

\begin{tabular}{cccc}
\hline NO & STUDENT NAME & PRE-TEST & POST TEST \\
\hline 1 & ARA & 20 & 60 \\
2 & APN & 20 & 100 \\
3 & AO & 70 & 90 \\
4 & AFS & 40 & 100 \\
5 & AFA & 60 & 100 \\
6 & AN & 60 & 100 \\
7 & DA & 60 & 90 \\
8 & DAP & 20 & 90 \\
9 & DPA & 90 & 100 \\
10 & EDS & 80 & 100 \\
11 & FA & 30 & 100 \\
12 & GJN & 60 & 100 \\
13 & F & 40 & 70 \\
14 & IFS & 40 & 90 \\
15 & MIM & 10 & 60 \\
\hline
\end{tabular}

Lexeme : Journal of Linguistics and Applied Linguistics, Vol 2(2), 2020 


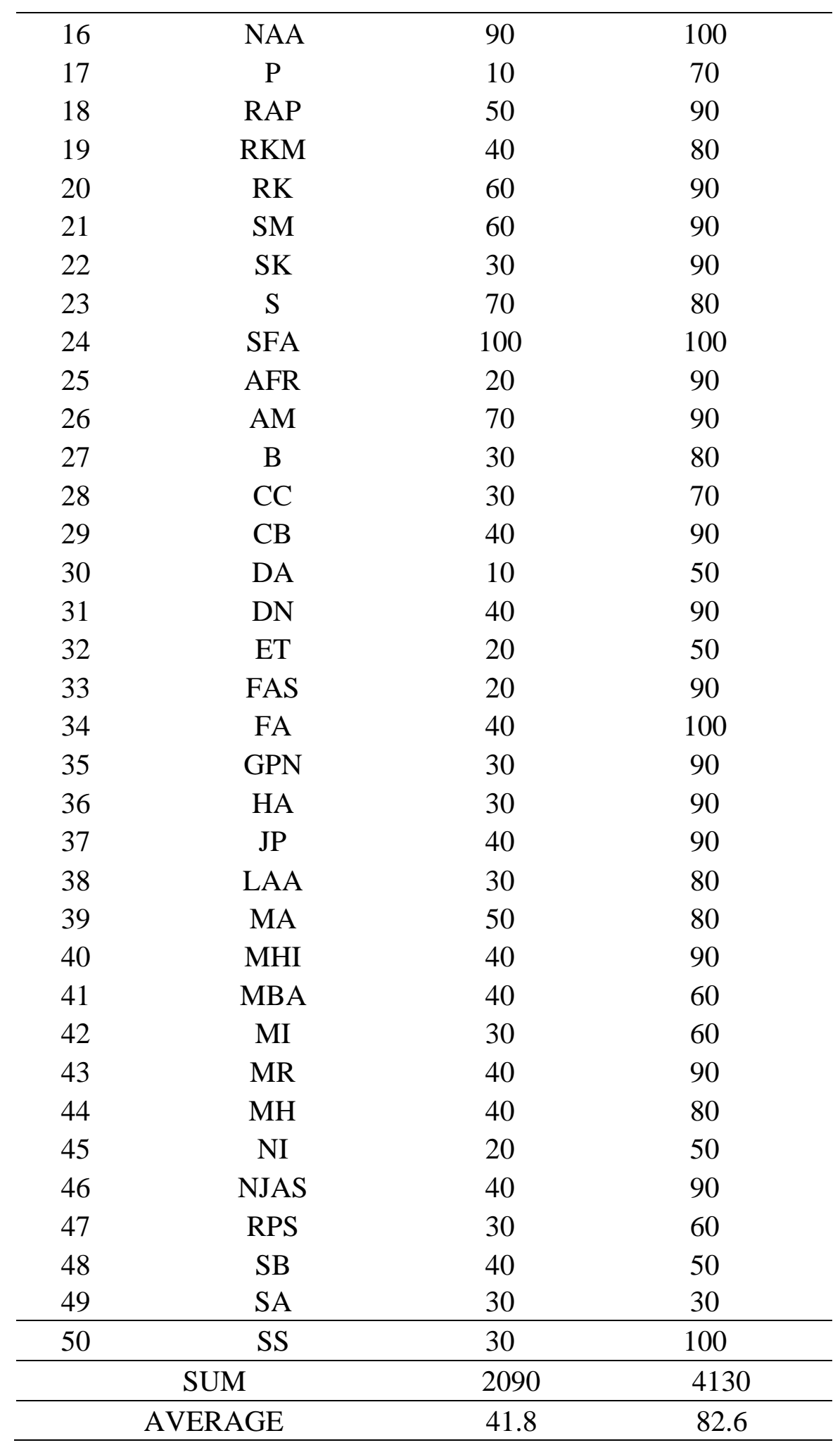

From the questionnaire given, there are some data presented to show student perception on learning English through Korean drama with English subtitle.

Table 2. The Percentage of Questionnaire Given

\begin{tabular}{llllll} 
NO & QUESTIONAIRE & YES & $\%$ & NO & $\%$ \\
\hline
\end{tabular}




\begin{tabular}{|c|c|c|c|c|c|}
\hline 1 & $\begin{array}{l}\text { Are you happy learning English through } \\
\text { Korean drama with English subtitle in } \\
\text { your class }\end{array}$ & 39 & $78 \%$ & 11 & $22 \%$ \\
\hline 2 & $\begin{array}{l}\text { Do you like learning English through } \\
\text { Korean Drama with English Subtitle in } \\
\text { your class }\end{array}$ & 42 & $84 \%$ & 8 & $16 \%$ \\
\hline 3 & $\begin{array}{l}\text { Does the Korean drama with English } \\
\text { subtitle make you enjoy English } \\
\text { learning process }\end{array}$ & 48 & $96 \%$ & 2 & $4 \%$ \\
\hline 4 & $\begin{array}{l}\text { Do you understand the dialog in Korean } \\
\text { Drama with English Subtitle }\end{array}$ & 50 & $100 \%$ & 0 & $0 \%$ \\
\hline $\mathrm{a}$ & $\begin{array}{l}\text { If yes, how can you understand the } \\
\text { dialogue of Korean Drama with English } \\
\text { Subtitle }\end{array}$ & & & & \\
\hline b & $\begin{array}{l}\text { In what extend can you understand the } \\
\text { dialogue of Korean Drama with English } \\
\text { Subtitle }\end{array}$ & & & & \\
\hline 7 & $\begin{array}{l}\text { Does Korean Drama with English } \\
\text { Subtitle encourage motivation to study } \\
\text { English, especially vocabulary? } \\
\text { Does Korean Drama with English }\end{array}$ & 45 & $90 \%$ & 5 & $10 \%$ \\
\hline 8 & $\begin{array}{l}\text { Subtitle help you memorizing English } \\
\text { Vocabulary? }\end{array}$ & 46 & $92 \%$ & 4 & $8 \%$ \\
\hline 9 & $\begin{array}{l}\text { Does Korean Drama with English } \\
\text { Subtitle help you to understand English } \\
\text { easier }\end{array}$ & 45 & $90 \%$ & 5 & $10 \%$ \\
\hline
\end{tabular}

Table 3. Clarification of Students Understanding Towards Korean Drama

\begin{tabular}{clc}
\hline NO & \multicolumn{1}{c}{$\begin{array}{c}\text { REASON CLASSIFICATION FOR } \\
\text { ANSWER YES IN NO 4 }\end{array}$} & STUDENTS \\
\hline 1 & English subtitle & 9 \\
2 & Artist Expression in Dialogue & 1 \\
3 & $\begin{array}{l}\text { Artist Expression in Dialogue then confirmed } \\
\text { to English Subtitle }\end{array}$ & 40 \\
\cline { 2 - 3 }$n$
\end{tabular}

\section{Is Korean Drama desirable to build learning communities in terms of improving English vocabulary?}

From the data result, the average of scores in Pre-Test is 41,8 . The pretest conducted after 60 minutes of learning process. Most students are below the passing grade. Surprisingly after the researcher applied Korean Drama with English Subtitle in English Vocabulary Learning, the score average showed significant progress, $82.6 \%$. The score data then confirmed to questionnaire result. The questionnaire showed that most of students feel happy, like and enjoy the process learning of English vocabularies by using Korean Drama with English sub tittle. It is confirmed by other questionnaire stated that most of students feel Korean Drama with English Subtitle has motivated them in learning English and help them to memorize and understand English words easier. 
From the score data, questionnaire result, and the observation result in the begining of the class, it showed that there is the feeling of happiness, like and enjoyment appear motivation and willingness to achieve their goal. It is supported by Buchanan and Huczynski (2019, p. 33) who argue that "motivation refers to reason that underlies behavior that is characterized by willingness which the intention to make behavior that is aimed at achieving a certain goal through initiation and monitoring." They add that the motivation comes from extrinsic and intrinsic factors. Extrinsic motivation refers to behavior that it is initiated by external factors. As well as teaching vocabulary through Korean Drama with English subtitle, the audiences are keeping watch Korean drama with English subtitle because they are interested in learning more about the storyline of Korean drama as their goal. As a result, people who are extrinsically motivated will perform their motivation into actions that are realized or not to achieve these goals. These actions are called intrinsic motivation. Morover, Pintrict in Lei (2011, p. 40) adds that "the intrinsic motivation is animated by personal enjoyment, interest, pleasure." In line with this, Risnawati (2014, p. 233) finds that students are often willing to learn without pressure. They tend to make more effort unconsciously. In terms of Korean Drama, reading English subtitles is an involuntary form of audience action in catching their desires delivering a feeling of comfort and fun. In this regard, English subtitle does not only play as the bridge that connects the audiences to the storyline of drama as their goals but also build learning communities that encourages student's competency of English vocabulary in spontaneous acquisition. Those findings lead to questions in what ways Korean Drama with English Subtitle improve English Vocabulary.

\section{In what ways, Korean Drama with English subtitle improve English vocabulary?}

The open questions in what ways students understand dialogue of Drama had been addressed to confirm to those who understand the dialogue. The data showed that all students understand the dialogue in Drama. Most of students confirmed artists' expression into English Subtitle. It indicates that the existing English subtitle is the bridge for audience to connect the mother tongue language of drama and the gestures of dialogue. It is in line to Sadiku (2018, p. 42). He proves in her research that at the beginning learners might sometimes face challenges in understanding video materials without being served with mother tongue language. However, this condition drives learners to try to understand the content of video by accessing spoken language and body gestures of the character playing in video that is not fully acquainted into subtitle. In this regard, the vocabulary acquisition occurs. It is in line with vocabulary learning steps, Hatch and Brown (2001, p. 84) state that there are some factors of learning vocabulary. They are having the source for encountering new words, getting a clear image for the form of new words, learning the meaning of words, making a strong memory connection between the form and the meaning of the words and performing or using the words. In the case of Korean Drama with English Subtitles, audiences' motivation to learn more storylines of Korean Drama encounters new words from subtitles then compares it into a clear image of the body gestures of the artist to confirm the meaning of the words. When the meaning of the words is processing well, it will form a strong memory connection between the new words and its meaning that belongs to vocabulary enrichment. Gorjian (2014, p. 1013) adds that human beings are able to remember $10 \%$ of what they hear, $20 \%$ of what they visually perceive and $80 \%$ of what they visually perceive and interact with. In terms of movie with subtitle, he added that students are not only watching and listening, but also interacting with it as they translate the source text into the target language. He points out that watching movies with English subtitle will drive students to give more efforts to understand what the body language and gestures of the actress are, and less effort to understand the input of the audio. As a result, the students pay more attention to subtitles which are in English. This leads to drive students to focus more on spelling of the words. It is in line with human capacity of remembrance mentioned by Gorijan that people 
have $80 \%$ visually perception and interaction. This condition help students recall these words in the future. Those give the evidence that English Subtitle forms a link between the motivation of the audience on Korean Drama and the step of vocabulary learning.

\section{CONCLUSSION AND SUGGESTION}

The finding results in this study showed that Korean Drama with English Subtitle can build learning communities in terms improving English Vocabulary. It makes students happy and enjoy English Learning Process. This feeling leads students to be motivated and helped in memorizing and understanding English word easier through confirming artist expression in dialogue into Subtitle. However, Korean Drama with English Subtitle in English teachinglearning process will not be able to support building learning communities in terms of improving English Vocabulary. Unless, it is supported by additional resources such as clearly learning instructional, book materials, module, textbooks, reference books, fostering students in preparation of learning and others that help students with their learning.

\section{REFRENCES}

Allen, K., \& Marquez, A. (2011). Teaching vocabulary with visual aids. Journal of Kao Ying Industrial \& Commercial Vocational High School, 1(9), 1-5.

Ani, Z. S., \& Adnani, K. (2017). HUBUNGAN ANTARA MOTIF DAN KEPUASAN PENONTON PADA TAYANGAN DRAMA KOREA (Uses and Gratification Pada Mahasiswa Jurusan Komunikasi Dan Penyiaran Islam IAIN Surakarta) (Doctoral dissertation, IAIN Surakarta).

Anggriani, D. (2013). IMPROVING STUDENTS VOCABULARY ACHIEVEMENT THROUGH WORD WALLS STRATEGY (Doctoral dissertation, UNIMED).

Bhakti, S., \& Marwanto, M. (2018). Vocabulary mastery by using storytelling. Script Journal: Journal of Linguistic and English Teaching, 3(1), 79-91.

Buchanan, D. A., \& Huczynski, A. A. (2019). Organizational behavior. Pearson UK.

Cresswell, J. W. (2003). Research design: qualitative and mixed-method approaches. 2nd edition, Thousand Oaks, CA; SAGE Publication

Cohen, L., \& Manion, L. (1994). Introduction: The nature of inquiry. Research methods in education, 4, 1-43.

Denscombe, M. (2014). The good research guide: for small-scale social research projects. McGraw-Hill Education (UK).

Esser, A. (2017). Form, platform and the formation of transnational audiences: A case study of how Danish TV drama series captured television viewers in the United Kingdom. Critical Studies in Television, 12(4), 411-429.

Hutafea, E. (2019) Belajar dari Korea Selatan: Riset Berbasis Kebutuhan Industri, https://edukasi.kompas.com/read/2019/08/20/18345511/belajar dari-korea selatan riset berbasis kebutuhan industri.

First, E. (2019). EF English proficiency index: A ranking of 100 countries and regions by English skills. Education First. Retrieved from https://www. ef. com/wwen/epi.

Hatch, E., \& Brown, C. (1995). Vocabulary, semantics, and language education. Cambridge University Press.

Gabelnick, F., MacGregor, J., Matthews, R. S., \& Smith, B. L. (1990). Learning Communities: Crating Connections Among Students, Faculty, and Disciplines. San Fransisco: Jossey Bass.

Gorjian, B. (2014). The effect of movie subtitling on incidental vocabulary learning among EFL learners. International Journal of Asian Social Science, 4(9), 1013-1026.

Huberman, A. M., Miles, M., \& Saldana, J. (2014). Qualitative data analysis: A methods sourcebook. New York : SAGE publications. 
Lai, E. R. (2011). Critical thinking: A literature review. Pearson's Research Reports, 6, 40-41

Marshall, C., \& Rossman, G.B, (2011). Designing Qualitative Research (5th ed). Thousand Oaks, CA: Sage Publication.

Mettetal, G. (2002). The what, why and how of classroom action research. Journal of the Scholarship of Teaching and Learning, 6-13.

Mustangin, M. (2018). Peningkatan Minat Baca dan Kemampuan Berbahasa Anak di Rumah Baca Bandung. Jurnal Imiah Pendidikan dan Pembelajaran, 2(2).131-141

Risnawati, R. (2014) Improving Vocabulary Mastery of the Eight Grade Students Through Song. e-Journal of ELTS (English Language Teaching Society), 2(4).233-234

Sadiku, A. (2018). The Role of Subtitled Movies on Students' Vocabulary Development. Int. J. Sci. Basic Appl. Res, 42, 212-221.

Shabiralyani, G., Hasan, K. S., Hamad, N., \& Iqbal, N. (2015). Impact of Visual Aids in Enhancing the Learning Process Case Research: District Dera Ghazi Khan. Journal of education and practice, 6(19), 226-233.

Susanto, A. (2017). The teaching of vocabulary: A perspective. Jurnal Kata: Penelitian Tentang Ilmu Bahasa Dan Sastra, 1(2), 182-191.

Wagner, C., Kawulich, B., \& Garner, M. (Eds.). (2012). Doing social research: A global context. McGraw-Hill Higher Education.

Waluyo, H. J. (2006). Pengembangan Model Pembelajaran Bahasa Indonesia dengan Pendekatan Apresiasi Drama.

Watkins, C. (2005). Classrooms as Learning Communities: What's in it for Schools?. Routledge. 